\title{
Térhasználat és szimbolikus szuverenitás
}

\section{Space-using and symbolical sovereignty}

\section{A. GERGELY ANDRÁS}

A. GERGELY András: tudományos főmunkatárs, MTA Társadalomtudományi Kutatóközpont, Politikatudományi Intézet, Budapest; a.gergely.andras@tk.mta.hu

KULCSSZAVAK: szuverenitás, szimbolikus politika, társadalmi tér, térhasználat, politikai antropológia

ABSZTRAKT: A tanulmány politikai antropológus szerzője elméleti kutatásnak veti alá a hazai térbeli identitások elméleti fogalmait, szimbolizációs és narratív viszonyrendszerét. A politikai cselekvések, projektek és önreprezentációs törekvések térbeliségének leképezése számos utat kínál az egyes szubkultúrák, értelmező közösségek politikai megjelenése számára. A szervezett politikai közélet és ennek kommunikációs univerzuma Magyarországon több időszakra bontható kapcsolatot mutat a diktatorikus, demokratikus, illetve a haladó és jelképekbe öltöztetett periódusokban, hasonlóképpen a tér antropológiáját politikai kontextusban vizsgálók tapasztalataihoz. A hatalom (hatalmi rendszer) megannyi térbeli megjelenítődése, az állam mindenhatóságának új nemzeti víziója ugyanakkor napjainkban is magába foglalja a haladásfogalom politikusok formálta térkiterjesztési eszközének szimbolikus politikai használatát.

András A. GERGELY: senior research fellow, Centre for Social Studies, Hungarian Academy of Sciences, Budapest; a.gergely.andras@tk.mta.hu

\section{KEYWORDS: social space, power distance, political anthropology, space-using}

ABSTRACT: In this paper the author examines whether there is a search for spatial identity in Hungary - similarly to theoretical notions of symbolisation tendencies - some virtual manifestation in a wide range of political actions, communicative relations of power distance in the way the multiplicity of spatial sub-cultures presents itself in politics. Following a theoretical introduction, the anthropologist author describes the significant communal interactions, the tradition consciousness and the processes of organising public life within a traditional political communication pattern. During the significant periods of Hungarian history, usually dictatorial ideas, disguised as democratic, progressive and symbolical power periods, some space and the representatives of power in the territorial order, the omnipotence of state and new "national" party-state in the external pressure of "progress" tailored by contemporary politicians have emerged.

The spatial scope of politics rarely becomes tangible, thus, its denomination also necessitates symbolic tools, a repertoire of analogous examples, and metaphoric interpretive space. Some of its elements (e.g.: representations concerning the boundary formation of freedom, violence, the limits of political environment or the legal code system) display a varied picture in particular historical periods, and form an even more complicated constellation of meanings if we examine the historical extent of space as a complex effect. With the aim of investigating the relation of space and society

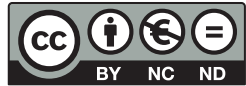


(in a deliberately reductive sense) and the symbolic dialogue of power and politics, I, in my essay, scrutinise the interpretive space, which appears as an exciting novelty to us: the symbolic (self)manifestation of space, and the effective validation of spatial presence, or at least the "outlining" of spatial boundaries.

The social sciences - which are forced to categorise to understand/be understood, but because of a compulsion for empirical self-validation, instead of the honorable or stigmatising classic categories of common sense, must keep the balance of the mechanisms of social effects and their respective scientific criticism (Bourdieu) - must comprehend and label the symbolic political field also. This is why Bourdieu (among others) believes that we should consider phenomena of social praxis, such as language, dialect, badges, stigmas, mental formulas, social representations, etc. both as mental and material representations. At the same time, we cannot separate social reality and its display from the struggle for the exclusive possession of power, which is aimed at the acceptance of the legitimate definition of the social world's division and its group-forming or group-terminating consequences. Thus, the stakes of the struggle is power, which can forcefully implement some kind of vision of the social world through division with the consensual definition of identity and unity, natural continuity and schism, origin-identity, and spatial identity. According to contemporary researchers, respective authority - which strives to create a division appropriate to its interests with revelations, authoritative rhetoric, and limits in the spatial domain - arbitrarily enforces certain territorial units, which, from the viewpoint of localities, do not coincide with borders of either origin, or cultural, economic, and political power relations (Bourdieu 1985, 7-22.). Bourdieu also emphasizes that the novel, symbolic division of the social world is a kind of performative utterance, which aims to establish what it speaks, and forces on those involved common principles of approach and division, which act through perceptual and receptive categories, that is, require a unified approach about identity and an identical approach to unity. This symbolic division of social space and the re-structuration of the social unit always has an institutionalised system of tools, the most exciting of which are acts performed in the struggle for recognition, appearing in the symbolic sphere. That which can be summarised here (considering the space available) is merely the survey of a fundamental question: how do politics and space relate? In my essay I focus on social "transport" or regulation, as well as a basic phenomenon of selective social perception, which I consider to be a basic constituent of social reality. It is not my aim to profusely discuss research trends or systemspecific phenomena, I merely make a disputable attempt to indicate what kinds of spatial concepts intrude on political public opinion and in what symbolic field these become part of public discourse. In my view, in a milieu of increasingly prolific philosophical and sociological issues under scrutiny, there is a dire need for an approach that gives emphasis to another dimension of social division, that of symbolic politics.

\section{Bevezetés}

A társadalomtudományok térfogalmai sokszor alakulnak (ki és át), köztük a saját tudományos tér maga is minduntalan formálódik, tágul és szűkül, függően attól, mire és miként használják azt, mit és hogyan konstruálnak belőle. Ki lehetne ugyan hangosítani a specifikusan kisebbségtudományi, tömeglélektani, emberföldrajzi olvasatokat, az alábbi írásban mégis inkább a térben élés, a térhasználat, a társadalmi tér forma- és fogalomváltozásának mozgásos dimenziói azok, melyeket körüljárni próbálok. „Körül” járom csupán, s nem mindig benne, bár ez utóbbi lenne alapcélom. De amit letapogatni szeretnék, valahol a tér antropológiája, a politikai diskurzusok és a narratív térformálás hármasában talál- 
ható. Korántsem ismeretlen, megismerhetetlen földrész ez, csupán az átláthatósága függ a terek ködösségétől, a távolságoktól, a rálátások szögétől, a belátások és fölismerések aktuális trendjeitől...

\section{A szimbolikus és a térpolitika}

Hozzá tudunk szokni ahhoz, hogy a tér mindig és mindannyiunk által átélhető, de (talán épp ezért, megragadhatóságának esetlegessége miatt is) az egyik legtalányosabb jelenséggé lett. Egyúttal egyike a legsajátabb, legszemélyesebb szféráinknak, létező entitásoknak, belakható szféráknak. Formálásának mindétig aktorai vagyunk, fogalmainak folyamatosan pontosítói és felülbírálói. De mindig „máshogy” tudjuk, mindenkor másképp beszéljük el, másra terjesztjük ki vagy szúkítjük be, mint mások. A politikához, annak egészéhez, fogalmi tüneményéhez való viszonyunk bár örök, de ugyanilyen eseti, olykor még kancsal vagy érdekvezérelt is. Minduntalan csak az a kérdés aktualizálható e változó viszonyban: hogyan fejeződik ki a politika a térben és miként jelenik meg a tér a politikában, továbbá hogyan éli át ezeket az egyén és a társadalom, s mennyiben érdeke kivonni vagy beleformálni önmagát is az adott, kinyert, létező vagy alakítható térbe, különösen ha az nem saját, hanem külső hatásokra kialakított.

Mint a legtöbb létszféra, a tér (a vele elsődlegesen foglalkozó fizikai, utóbb a település- és tértudományok szerint) leginkább földrajzi kiterjedésében ragadható meg. Azonban egyre gyakrabban figyelem fordul arra is, hogy a filozófiai, politológiai, szociológiai és antropológiai megközelítés kiegészíti, olykor felülrétegzi a humánföldrajzi tapasztalatot. Ezért nemcsak a térfelfogások sokfélesége, hanem a szimbolikus szférák felé is kitérőt kell tennünk. Ugyanis a társadalmi térképzeteket leggyakrabban a szimbolikus formák és szimbolikus funkciók hordozzák, amelyeket a közvélekedés úgy értelmez, mintha bizony a szimbólumok egyezményes jelek lennének, a térbeliségnek adott formái pedig olvasatokat írnának elő. Többféle szaktudományos tapasztalat utal azonban arra, hogy a társadalmilag közölt jel nem okvetlenül befolyásol tömegjelenségként, a szimbólum (a jelentéshordozó) igen. Mi több, a társadalmi befolyásolásban előállított jelek és jelzések szimbolikus funkciója éppen a posztmodern korszakban nyerte vissza kényszer- és elöírásmentes állapotát, leíró narratíváik ugyanakkor közelebb is kerültek a társadalmi közbeszédben és a köznapi kommunikációban divatossá vagy aktualizálttá vált fogalmakhoz. Olyanokhoz, mint a plurális demokrácia, a szuverenitás, a modernizáció, amelyeknek térfogalmai akként lettek a kommunikációs terek részei, hogy a társadalmi párbeszédekben feladók és vevők, közlők és befogadók, termelők és fogyasztók szféráira oszthatókká váltak (lásd például a „világháló”, a természetfölöttivel való kommunikáció, az „uniós normatívák”, a „globális felmelegedés” vagy a „nemzetközi szolidaritás” megfoghatatlanul puha, mégis a képzelt társadalmi térbe/terekbe illeszkedően „egzaktnak” tetsző fogalomkészletét). 
Ilyesfajta szimbolikus szférák elemzésekor számos társadalomkutató elemző szempontjait vehetnénk példának. Napjainkban - megannyi történeti térben már ismertnek tekintett - tünemény mellett (lásd „birodalomépítés”, „a keresztény világ”, „egyházi érdekek”, „világproletariátus”, „emlékezetpolitika”, „a civilizáció határai”, „felszabadult gyarmatbirodalom”, „millenarista mozgalmak”, „konzervatív Európa" stb.) a politikai élet számos területe szimbolizálódik, olykor önálló életre kelve összeolvad/társul más jelentésekkel, s gyakorta a szimbolikus és a valóságos közötti terület válik a társadalmilag átélhető identitás alapjává (ne menjünk messzebb: Nagy-Magyarország virtuális képe, az uralkodó elithez tartozás, a „kiskerttulajdonosok közössége”, az innovációs térpotenciál, a zenei szubkultúrák természetrajza, a tudáselit rangja, a rozsdaövezeti biokertmozgalom, a Krisna-tudatú hívőközösség, a „szülőföldre” hazatérés, a határon túliság, a mentális örökségvédelem stb.). A szimbolikus megjelenítődés ${ }^{1}$ olykor csupán helyettesít valódi politikai aktusokat, tartalmakat, s egyebek között a tér fogalma is ilyen jelképiséget rejt magában. Az antropológus Lévi-Strauss (1958) szerint a tér nem egyszerüen valamely valóságos terület, nem is a képzelet kiterjesztésének helye, hanem egy merőben strukturális elem, mondhatni topológiai, ezért egy tér (spacium) helyei (places) tisztán struktúraalkotó elemek, ami lehetővé teszi, hogy azt valami valóságos elem betöltse (Deleuze 1973). A térrel kapcsolatos antropológiai felfogások több kötetre rúgnak, fölidézésük meghaladná dolgozatom kereteit (a téma egy feldolgozásáról lásd Paul-Lévy, Segaud 1983, vagy egy aktualizált másikat Zombory Máté, 2011 áttekintésében). Értelmezésem szerint a konkrét fizikai tér „fölött” (körül) mindig valamely szimbolikus tér is megtalálható (így pl. a politikai intézményekhez rendelődött historikus konnotációk, pártszékházak vagy börtönök, bíróságok bűvköre, ,,jelentéstörténetek", hierarchiák vagy a hatalom potencialitását övező szimbolikus eröfölény, a törvények hatótere, a nyilvánosság jelképes szférája stb.), a társadalmi magatartásokat pedig gyakorta a szimbolikus cselekvések jellemzik, amelyek rendszerint konfliktusosak, s adott esetben sokszor intenzívebbek, mint a valóságos cselekvések (lásd pl. Harrison 1995).

A politika makroszféráját rendszerint átható szimbolikus politikai gondolkodásban gyakorta előfordul, hogy a hatalom meglévő távolsága és idegensége egyszerüen úgy szimbolizálódik, mint „rendezett valóság” és annak szervez” elveként objektiválódó jelenség (utalok arra, amit az állam vagy terület, az uralmi tér, a birodalmi kiterjedés, a nemzetközi kapcsolatrend, a biztonsági övezet stb. jelent). A hatalom szimbolikussága jószerivel a legerősebb eszköznek nevezhetö, amelyben a társadalmi közösség folytonosságának, állandós(ultság)ának nyilvánvalósága (históriája, élettere, uralmi miliője) válik képzetessé. Holott a tényleges hatalmi kapcsolat és a szimbolikus kapcsolat nincs közvetlen egymásrahatásban, nem redukálható egyik a másikra, merthogy a szimbólum nem valamiféle mechanikus reflexió vagy a politikai valóság egyszerű reprezentációja, hanem nagymértékben függ az őt körülvevő értéktértől, az egyes társadalmi csoportok értékszelekciós attitűdjeitől, illetve végső soron kiszolgáltatott magának a szim- 
bolikus tökeképződés folyamatának is. ${ }^{2}$ Ám végső soron éppen erre a szimbolikus hatalmi mezőre akaszkodik rá egy réges-régi fogalmi képződmény, a szuverenitás. Vagyis az a képzet, hogy a főhatalom müködési tere és a szabadság (állampolgári vagy államnemzeti szintü) értéktere valamely ponton összefut, s ez a tér lesz a szuverenitás beágyazottságának, kiterjedésének és érvényesülésének biztosítéka. Carl Schmitt szerint a főhatalom gyökere mindig az akarat, ezért szuverén csak az lehet, aki akarattal és parancsolási eszköztárral rendelkezik, s aki a kivételes állapotról dönthet (Schmitt 1992, 1-7., 146.). Gombár Csaba és a Korridor Mühely egész kötetet szentel a szuverenitás térfogalmi kiterjedéseinek tisztázására (1996); N. Kovács Tímea (2007) példás monográfiájában a helyek, kultúrák, szövegszerűen megjelenített világok kulturális antropológiai dimenzióit járja körül; Eric Hobsbawm (pl. 2009) számos müvében a történészek lankadó figyelmére fókuszálja érdeklődését, egyebek között a mindennapi tereinkben lakozó névtelen hősök korszak- és térmeghatározó jelentőségét hangsúlyozva; Kapitány Ágnes és Gábor (2013) a társadalmi és mentális-morális terekben zajló „szellemi termelési mód” igazi kiterjedését emelik fókuszba; az európai társadalmi tér és a globalizáció viszonyát bevonva e tárgykörbe Ulrich Beck rendezi el a modernitás új szakaszainak jelentésterét (Beck, Grande 2007); Valuch Tibor (2013) sajátos retrospektív perspektívát nyit, amikor a mindennapi élet menetében korszakos térdinamikák helyzetmeghatározó és változási dinamikákat is hordozó (jövedelem, lakás, lakótér, fogyasztás, divat, táplálkozás) jelentőségére vezeti figyelmünket a második világháborútól az ezredfordulóig jellemezhető városi, vidéki, tájegységi, rétegződési terekben. $\mathrm{S}$ akkor még szégyenszemre nem említettem a „teresedések” olyasfajta szakirodalmát, melyet a történészek (pl. Gyáni Gábor, Kövér György, Granasztói Péter, Ö. Kovács József), a kommunikációkutatók (Terestyéni Tamás, Kiss Balázs, Antalóczy Tímea, Gagyi József, Szijártó Zsolt, Bugovics Zoltán, Császi Lajos), a vallási térfolyamatok elemzői (Vincze Kata Zsófia, Máté-Tóth András, Kamarás István, Farkas Judit, Papp Richárd, Bögre Zsuzsa, Póczik Szilveszter, Barna Gábor, Szász Antónia), a kultúrakutatók (Kovács Éva, Tibori Timea, Biczó Gábor, Feischmidt Margit, Fejős Zoltán, Pusztai Bertalan, Géczy János, Ilyés Zoltán, Keszeg Vilmos, Tánczos Vilmos, Kolozsi Ádám, Ilyés Zoltán), társadalomnéprajzosok (Sárkány Mihály, Vargyas Gábor, Keményfi Róbert, Szarvas Zsuzsa, Szuhay Péter, Nagy Zoltán, Michael Stewart, Pócs Éva), továbbá régiókutatók, afrikanisták, szociálpszichológusok, romológusok, struktúrakutatók, kulturális menedzserek vagy épp kulturális antropológusok (végtelen a névsor!) a térbeliséggel összefüggésben az elmúlt években-évtizedekben felszínre hoztak vagy interpretációikkal vettek körül (lásd ehhez A. Gergely 2014a, 2014b).

Mindemellett korunk társadalom- és politikatudománya kénytelen minduntalan szembesülni azzal a feltételrendszerrel, amely a politikai tér elfoglalásának, megőrzésének és folytonos felügyeletének jelenségegyüttesét hordozza a gyakorlatban. Minél messzebbre megyünk vissza a társadalmak történetében, annál sokrétúbbé válik a társadalmi tér használatáról és a politikai tér szimbo- 
likus elkülönüléséről megfogalmazható tapasztalat. A politika térbeli kiterjedése azonban rendkívül ritkán válik „kézzelfoghatóvá”, ezért megnevezéséhez is szimbolikus eszköztár, analógiás példatár, metaforikus jelentéstér szükségeltetik. Ennek egyes elemei (például a szabadsággal, az erőszakkal, a politikai környezet határainak vagy a jogi környezet kódrendszerének kialakításával kapcsolatos reprezentációk) meglehetősen változatos képet mutatnak az egyes történelmi korokban, s még ennél is bonyolultabb jelentésegyüttesbe szerveződnek, ha a tér történeti kiterjedését mint hatáskomplexumot tanulmányozzuk. Tér és társadalom viszonyában (szándékosan szűkítő értelemben) hatalom és politika jelképes párbeszédének vizsgálata céljával az alábbiakban azt a jelentésteret fogom megfigyelés tárgyává tenni, amelynek pontosan a tér szimbolikus kifejeződése (mutatkozás), a térbeli jelenlét hatékony érvényesítése (kiterjesztés) vagy legalábbis a térbeli határok „körülrajzolása” (reprezentáció, narratíva) az izgalmas tétje számunkra (korábbi verziókat, megközelítéseket tartalmaz például A. Gergely 1994a, 1994b, 1995).

A társadalomtudományok, amelyek a megismerés érdekében osztályozni kénytelenek, de empirikus önigazolási kényszereik miatt a józan ész kitüntető vagy megbélyegző klasszikus kategóriái helyett szükségképpen a társadalmi hatások mechanizmusait és az ezekről kialakítható tudományos kritikát kell egyensúlyban tartsák - mint erre Bourdieu már a hetvenes évektől figyelmeztet -, a szimbolikus politikai mezőt is át kell lássák és néven kell nevezzék. Ezért tartja fontosnak Bourdieu, hogy a társadalmi gyakorlat olyan jelenségeit, amilyenek a nyelv, a dialektus, a jelvények, a stigmák, a mentális képletek, a társadalmi képviseletek stb., a mentális reprezentációk és tárgyi reprezentációk formájában is figyelembe vegyük. A társadalmi valóság és annak megjelenítése ugyanakkor - érvel tovább - nem függetleníthető a hatalom kizárólagos birtoklásáért folyó harctól, amely a társadalmi világ felosztásának legitim definíciójára és csoportteremtő vagy csoportmegszüntető következményeinek elfogadtatására irányul. A harc tétje tehát olyan hatalom, amely kikényszerítheti a társadalmi világ valamifajta vízióját a divízió, vagyis a fölosztás által, azonosság és egység, természetes folytonosság és szakadás, eredetidentitás és téridentitás közmegegyezéses definíciójával. Bourdieu szerint a mindenkori autoritás, amely kinyilatkoztatásaival, tekintélybeszédjével és a tér tartományában megvalósított határolásokkal igyekszik létrehívni a maga érdekeinek megfelelő fölosztást, önkényesen kényszerít ki sajátos területi egységeket, amelyek a lokalitások szempontjából sem az eredet, sem a kulturális, gazdasági vagy politikai erőviszonyhatárokkal nem esnek egybe (Bourdieu 1985, 7-22.). Ugyancsak ő fejtette ki, hogy a társadalmi világ ez új, szimbolikus felosztása egyfajta performatív beszéd, amely azt akarja, hogy amit kimond, az meg is legyen, s rákényszerít az érintettekre olyan közös szemléleti és fölosztási elveket, amelyek percepciós és recepciós kategóriák által hatnak, vagyis egységes szemlélet kívánnak az azonosságról és azonos szemléletet az egységről (Bourdieu, Boltanski 1975). 
A társadalmi tér e jelképes felosztásának és a társadalmi egység e felosztások általi átstrukturálásának mindig megvan a maga intézményesített eszközrendszere, s különösen a szimbolikus szférában megfogalmazódó, az elismertségért folyó küzdelemben kinyilvánított aktusai izgalmasak. Amit erről itt (terjedelmi okok miatt csupán) összegezni lehet, az mintegy szemlézése egy alapkérdésnek: politika és tér kapcsolatának. Az alábbiakban a társadalmi „közlekedés”, illetve szabályozás, valamint a szelektív társadalmi észlelés egyik alapvető jelenségére koncentrálok, amelyet úgy tekintek, mint a társadalmi valóság egyik alkotóelemét. Nem célom kutatási irányzatok vagy rendszerspecifikus jelenségek kimerítő tárgyalása, így a maga vitathatóságában mindössze azt jelzem, milyen térfogalmaink és térképzeteink tolakodtak be a politikai közgondolkodásba, s milyen szimbolikus mezőben válnak ezek nyilvános diskurzusok részévé. Úgy látom: az egyre sokasodó filozófiai és szociológiai tisztázási kísérletek mellett mindinkább szükségeltetik egy, a társadalmi osztottság más dimenzióira figyelemmel lévő közelítésmód idekapcsolása, mégpedig a szimbolikus politikáé.

Mielőtt azonban e kérdéskörben elmerülnék, két pontosításra kell vállalkoznom. Amikor térről beszélek, az idő mozgását értem alatta, s időnek a tér folyamatát, kiterjedését gondolom. A térről szólva tehát nem pusztán természeti területet, biológiai zónát vagy településföldrajzi jelenséget veszek alapul, hanem olyan szociábilis képződményre célzok, amelyet nem csupán geográfiai értelemben vagy a gazdasági és társadalmi szerkezet létrehozta mezőben lehet körülhatárolni (ilyen lehetne a „táj” fogalma vagy az „ökotáj” jelentéstöbblete is). Hanem emberi magatartások, kulturális együtthatások, integrációs folyamatok eredményeként kialakult (vagy csak megnevezett), sajátos „mi”-tudattal elsajátított, főképpen jelképes kizárásokkal és határokkal definiált virtuális valóságszeletre gondolok, amely akkor válik megnevezhetővé, ha átélésének lehetősége adott és a köztudatban meg is képződik. Gyáni Gábor (2010), amikor az időről és az emlékezés mint történetmesélés korszakos tüneményeiről beszél, egyértelművé teszi, hogy a jelenbeli múlt, a múltbeli aktualitás, a felejtés és megtartás, az emlékezet és törlés mint eseménysorok váltakozása nem csupán valamely távolságtartó messzeség vagy értelmezői rendszerezőkészség tartozékai, hanem az élő, időben létező, társadalmiságba belevetettségükben a maguk másságát megélő emberi csoportok mentális védekezési eszköze a térben is, melyben nincs az a „kis hely”, amelyből ne lehetne „nagy történéseket” kiolvasni-megérteni, amennyiben a „mikro” nem kizárólagosan az érdektelennek tetszo helyit, a „provinciálisan” poros jellegtelent és az elnagyolt „általánost” jelenti, hanem a helyi mivoltában is univerzálisabb jelentést hordozó reprezentációt is magába foglalja, megtestesítve hosszú időtávú folyamatokat. Bugovics Zoltán (2004) pedig, amikor a nyugat-magyarországi térség öndefiníciós kérdéseit elemzi társadalomföldrajzi dimenzióban, rálel az identitásrégió néprajzosok-antropológusok és történészek számára is hangsúlyossá vált kérdéskörére (lásd továbbá Ilyés 2005), ezen belül a történeti és térbeli tagozódás gazdasági 
és mentális mutatkozásaira. A térben lakozás, térbe fogalmazott hovátartozás persze korántsem új jelenség, a klasszikus antik irodalomtól a modern világgazdasági tagolódásig és a posztgyarmati újrafelosztások politikatörténetéig megannyi verzió létezik. Claus Offe (1991) például háromosztatú modellben írja le a politikai hatalom küzdőtereit: az államapparátus politikai elitszintjének, az anonim csoportok és kollektív cselekvők szintjének, valamint a kommunikációs áramlatok és a politikai kultúra szintjének viszonyában, s e három szint a valóságra vonatkozó definíciók segítségével verseng kulturális hegemóniáért, a politikai erők uralmi szférájáért. Vagyis a küzdőterek kölcsönhatása nem egykönnyen tettenérhetö, s a harc nem közvetlenül pénzért vagy hatalomért, hanem olykor csupán a definíciókért, s magáért a saját tér definiálásának jogáért folyik (Habermas 1994, 304-305.). Ebben az értelemben használom hasonló jelentésben a „mezö”, a „szféra”, a „tartomány”, a „terület” vagy a „territórium” kifejezéseket (nem kívánok persze összemosni közöttük meglévő értelmezési vagy jelentéskülönbségeket!). Az ilyen terekben zajló csatározások, mivel javarészt észrevétlenek maradnak a köznapi mikrokommunikáció szintjén, s csupán esetenként sürüsödnek politikai cselekvéssé, lehetővé teszik az autonóm nyilvánosságok és kommunikációk kialakulását, amelyek egy önszervezési „küszöb” alatt erősítik a kollektív cselekvőképességet, s ezen az úton alakul ki végül is a „magánterülettel” szemben vagy összefüggésben a habermasi nyilvánosság, amely maga is egyfajta területként objektiválódik (Habermas 1971, 10-11.). A nyilvánosság pedig szervesen illeszkedik egyfelől a kultúra világába, amely mint az emberek által szőtt jelentések világa „nem törvényt kereső kísérleti tudomány tárgya, hanem jelentés nyomába szegődő értelmező tudomány" eszköze (írja Geertz 1988, 16.), másfelől pedig mindezen jelenségek együttese „a politika parttalan világába" tartozik (Gombár 1986), s így a politikai kérdések tematizálásának eszközéül szolgál.

A térfelfogás és „a” hatalom terének körülhatárolása tehát társadalomés politikatörténeti alapkérdés, noha földrajzi köntösbe öltöztetik legkényelmesebben. Ezért a másik pontosításom a politikára kell vonatkozzon, amelyet nem tekintek (szemben számos szcientifizált megközelítéssel) csupán egynek az alrendszerek közül, ugyanakkor nem is állítom, hogy mindenben teljeséggel megjeleníti magát. Úgy vélem, hogy a legátfogóbb politikaképet éppen az uralmi tér definíciójával, az éppen adott állapot körülcövekelésével kell fogalmilag szükíteni, s lehetőség szerint nyomon kell követni ennek nyilvánvaló vagy jelentéses változásait. Ezért amikor uralmi térról beszélek, arra gondolok, hogy a politikai hatalom területi eloszlásának dinamikájától meghatározott irányítási döntéspotenciálnak lokális megjelenéséről van szó, amely a hatalomgyakorlási funkciók hierarchiájától függő nagyságú és erősségű. Alábbi gondolatmenetem következésképp a szimbolikus szférában megjelenő, változó erősségű és nagyságú kompetencia kiterjesztéséről szól, amelyet tér és politikum tartományában a hatalom szuverenitása és e szuverenitás kifejeződése szempontjából próbálok megfigyelni. 


\section{Antropológiai és politikai terek}

A térbeliség fogalma a politikai antropológiában H. Sumner Maine (1959) és Lewis Henry Morgan (1961) kutatásaira megy vissza (a 19. század delére), akik egyrészt a jogrendszer, másfelől a társadalomszervezet kontextusában keresték a politika megjelenésének módozatait, a térségi és társadalmi kapcsolatok megjelenésmódját (a „biológiai hazafiságtól” a „földrajzi hazafiság” felé átalakulást). Hozzájuk képest a szociálantropológus Robert Harry Lowie (1962), aki a legelsők egyikeként (könyvének első kiadása 1920-ban jelent meg) foglalkozott politikai antropológiai témával, az állam eredetével, a kormányzással és a bíráskodással, meghaladta elődeit abban, hogy bemutatta a rokonsági rendszertől a területi szerveződés felé tartó átmenet formáinak lehetőségét, illetve jelentőségét, hisz e két típus nem zárja ki egymást. Mások, pl. Bronislaw Malinowski (1960) vagy Polányi Károly $(1972,244$.$) a primitív vagy archaikus társadalom térbeli szerveződésfor-$ máinak komplex intézményrendszerét elemezték, létfontosságú jóléti-szociabilitási funkciókat ellátó, ugyanakkor az archaikus társadalom stabilitását biztosító eszközöket, amelyek a korai államképződményekben „időtlen erőként” biztosították az állam létesülése előtti társadalomszervezet kontinuus fennmaradását és térbeli állandóságát. Evans-Pritchard (1940), valamint Fortes és Evans-Pritchard (1940) már az állam szerepének és az állam nélküli társadalmaknak szimbolikus megjelenítődését taglalták, kifejtve, hogy a hatalom térbeni megjelenését koncentrikus körökkel lehet leírni, de a központi hatalomtól távolodva egyre csökken az intézményes hatás. Radcliffe-Brown $(1952,1971)$ pedig a primitív társadalmak „szervezett anarchiájának”, illetve a társadalomszervezet fölött gyakorolt uralom elfogadásának területi sajátosságait mutatta ki, megfogalmazva, hogy a politikai szervezetrendszer olyan totális intézmény, amely a fizikai erők fölötti ellenőrzés és a szabályozás feladatát látja el, s ennek a belső térben a jog, a külsőben a háború az eszköze. Csupán megerősítésképpen jelzem: térfogalmakról, ezek rendszeréről vagy szuverén jelentéséről van szó, melyek mindeközben a hatalomgyakorlás intézményességét, eszköztárát is meg- vagy kiteljesítik...

Az erőszak és fennhatóság, alávetés és uralomtechnika kérdését tekintve a korai politikai antropológusok a 20. századi elméleti vitákon kívül szembetalálkoztak azzal a problematikával, amelyben az antropológia feladata a gyarmati rendszer, a gyarmati berendezkedés és terjeszkedés szolgálata volt, de ezzel együtt is úttörő munkát vállaltak az indirekt hatalmi adminisztráció hatékonyságát növelő térbeli politikai befolyás gyakorlatában. Ám kutatásaik révén egyúttal olyan térfogalom terjedt el, amely (szándékuktól függetlenül) az Európán kívüli vagy nem európai társadalmi fejlődés elmaradottságáról kialakult felvilágosodáskori politikai filozófia hatását tükrözte, amely a fejlődéselméletek és a nemzetállami politikai hübrisz hatására a bennszülött civilizációk „elmaradottságát" illette kritikával, mivel azok nem hasonlítottak az európai államiság intézményeire, alakzataira. A politikai antropológia térképzetét a későbbiekben, főként a 20. század második harmadában, a gyarmati függetlenségi harcok fel- 
lángolásának időszakában nagymértékben szélesítette a megváltozó mozgásterek elemzése, majd pedig a gazdaságelméletből, szociológiából és szociálpszichológiából átvett centrum-periféria dimenziók belátása, „téri” átfogalmazása is.

$\mathrm{Az}$ antropológia-történet során többször lett megfontolások tárgya a Ratzel (1882-1891) munkásságából ismertté vált „marginális zónák” elmélete, vagyis az elszigetelt térbeli-kulturális elterjedési területek olyasfajta tipológiája, amely a kulturális rétegek és minőségek hierarchiáját fogalmazza meg. A társadalmi és gazdasági egyenlőtlenségek nemzetközi rendszerében és a világgazdaság makrostrukturális térfogalmában már egy szintén újabb korszak gondolkodásmódja érvényesült (Arrighi 1991; Gunder-Frank 1991; Wallerstein 1991 munkáiban), amelyet a legutóbbi negyedszázadban kiegészített a „szép, ami kicsi” Schumpetertől (1980) eredő szemléletének újrafölismert, mikroökonómiai léptékủ felfogásmódja (dominánsan Augé 1992, Appadurai, Beck, Ilyés, Krasznai, N. Kovács művei képezik ennek megjelenítését). Ezen előzmények után korántsem véletlen, hogy a kulturális antropológia és a kortárs szociológia az archaikus gazdaságból és munkamegosztásból vezette le a nagytérségi gazdaságok működési logikáját, továbbá a „felhalmozás legértékesebb formáját”, a szimbolikus tőke kialakulását is, amit (mintegy negyed-fél évszázaddal az említett korai antropológiai elemzések után) Marcel Mauss és később Pierre Bourdieu vizsgáltak meg újra (Bourdieu 1978; Mauss 1950). Mauss pillantása Melanézia, Polinézia, Észak-Amerika mellett a hindu, kelta, germán és kínai cserekapcsolati szokások, ajándékozási szertartások térbeliséget konstruáló szerepére is kiterjed, Bourdieu számára meg a szimbolikus javak a szimbolikus csere eszközei, melyek az archaikus és kortárs gazdaságban leképezhetők mindenütt, ahol a föld, vagyis a társadalom gazdasági terének szimbolikus értékét az a történeti kapcsolat határozza meg, amelyet annak birtokosa és a valamiképpen álcázott birtoklás- vagy uralomforma közötti viszony jellemez (Bourdieu 1978, 399.).

Egyszóval az uralom módja, térbelisége és a szimbolikus legitimitás között Bourdieu is alapvetően meghatározott viszonyt feltételezett. Foucault pedig, aki szerint „a fegyelem analitikus teret szervez”, a törvénykezési-politikai funkciók között a legyőzhetetlen hatalomra jellemző tevékenység-ellenőrzést „a felosztás művészetének" minősítette, s a fó funkciót ebben nem a hatalom öncélú eredményességének biztosításaként látta, hanem a társadalmi erők megszilárdításának feladatát, a modern térbeliségszemlélet (vö. panoptikusság) megjelenését (Foucault 1990, 283.). Mauss, Bourdieu és Foucault szellemének idézése azért fontos, mert épp a szükségletek garantálásának nemzetállami keretek közötti (globálisökológiai válsággá vált) problematikája erősítette fel a szuverenitás, a nemzeti és politikai, civil társadalmi és hatalmi önrendelkezés kérdéseit. Mégpedig úgy, hogy e tekintetben már jelen volt a térbeliségnek földrajzi, társadalomrajzi és funkcionális leírása, hisz azokból majdan a modern társadalmi rendszerek legitimitásának alapkételye fejlődött ki. Azaz: a tér mint uralom esélye, a hatalom mint térbeli kiterjedés, a kétségtelenül fogalmi szintre emelt politikai magatartások befogadó közege érvényesül mindenütt, s ha fizikai értelemben nem is mindig, de 
a tőkefunkciók, alárendelések, alkukényszerek, kiszolgáltatottságok formájában állandósulva.

Látható tehát, hogy a szociológiai (és az általában vett társadalomelméleti) tematizálások sok tekintetben gazdagodtak az antropológiai hagyományból. A politikai antropológia mai vizsgálódásai pedig már egyenesen a politikai főhatalom modern intézményeit, az autoritások átalakulási folyamatait és a befolyásolás árnyaltabb, szimbolikusabb mechanizmusait tárják fel, s a kutatások olykor még mindig (elnyomottak, alávetettek iránti) elfogultságot tükröznek, de immáron nem a leigázó, a területfoglaló nagyhatalmi erőszak, „a fejlődés irányítását" kézben tartó beavatkozó politika szolgálatában állnak, hanem épp ellenkezőleg: a lokalitások, a térbeli-települési egységek, az etnikumok felől tekintenek az állam központi intézményeire, és az etnikumok saját, az államival rendszerint gyökeresen szemben álló helyi intézményeit részesítik előnyben. Ennek a perspektívaváltásnak fél évszázadon belüli látványos lezajlása teszi indokolttá, hogy a térbeliség, a társadalmi és a politikai térben megjelenő térképzetek sokszínűségét vizsgáljuk.

Természetesen nem térhetek ki a térátélés minden módjára és mértékére, a globalizálódó világgazdaságtól az emberi pszichéig, hiszen a felfogások szukkszavú ismertetése is kötetnyi munkát igényelne, ezen kívül sokan elemezték ezeket a problematikákat már előttem is. Ami számunkra az antropológiai kutatásokból kiemelendően fontos lehet, az a társadalom politikai tagoltságának térbeli önkifejeződése a lokalitások nézőpontjából, ami szükségképpen a politikai mezőben, illetve a politikai palettán megjelenő pártok, képviseletek, normák, értékek helyi és országossá növesztett intézményeiben jelentkezik, helyenként pedig a civil társadalomban (vö. politikai földrajz, etnikai földrajz). Az intézményesülésben végbemenő önérvényesítés számos szimbolikus és tényleges politikai erőhatás reprezentálója - ezek közül most csak a jelképhordozó, szemantikailag is kifejeződő néhány momentum tematizálására vállalkozom. ${ }^{3}$ A kapcsolódó problematikák részletes elemzésére itt nem törekedhetek, $\mathrm{s}$ a kortárs társadalmi történések idejében példákkal sem próbálok messzebbre menni a hazai rendszerváltás kezdeténél (amelynek egyébként valódi megtörténte a társadalmi és politikai tér eltérő szintjein másként és másként volt átélhető, így a rurális Magyarországon sok helyütt maga a rendszerváltozás élménye is elmaradt, vagy a „változás”, „változtatás”, „váltás”, „átmenet” fogalmi vitájába fulladt). Nem a magyar rendszerváltoztatás kérdésében, hanem az átélhető valóság társadalmi felépítésének alapmodelljében is meggyőző az állítása a Berger és Luckmann szerzőpárosnak, hogy a mindennapi valóság „fölötti” társadalmi konstrukció olyan térfogalmakkal operál, melyeknek nem okvetlenül van fizikai és empirikus formája is, de ettől még éppoly valóságosként, interszubjektív entitásként átélhetőek (bővebben lásd Berger, Luckmann 1998). Épp ezért a „váltás”, „változás” intraszubjektív átélése és közösségi kommunikálása azt a teret formálja meg, 
melyben a társadalmi közösség mindennapi életvitelét vagy akár rendszerváltoztató hétköznapjait is átéli. Ezt a teret most tovább nem taglalom, lévén itt nem pusztán a percepcióról, hanem a formálásról és foglalásról van szó, avagy a valóságpercepciók mellett a térbeélés empirikus szférájáról. ${ }^{4}$

\section{Szimbolikus térfoglalások, térbeli osztottság}

„Az uralmi kapcsolatok tisztán politikai terét a hatalmaknak és a javaknak a földrajzi térben való elosztásának, és a szereplő személyeknek ebben a térben való eloszlásának kapcsolata határozza meg; a javaktól és a hatalmaktól való földrajzi távolság jó mutatója a hatalomnak" - írja Bourdieu $(1985,19$.$) . E logi-$ kával végiggondolva a szimbolikus javak hazai piacának eseményeit és játszmáit, láthatóvá válik, hogy nemcsak a magyar társadalom egyre erősödő érdekkülönbségei „szimbolizálódtak” a politikai szférában, de a politikai küzdelmek központi vagy helyi szereplői is látványosan eltérő befolyással rendelkeztek ugyanott, s ennek alapján igen eltérő játszmákat folytattak az elmúlt évtizedekben (lásd önkormányzatiság, területi politikák, térségtanulmányok a hazai regionális, humán- vagy politikai földrajzban). A gazdasági vagy szimbolikus térben megjelenő integráló hatások nem csupán az intézményellenes körülményeknek és szándékoknak kedveztek (pártfinanszírozások rendszere, médiauralom centralizálása, önkormányzatiság korlátozása, közjogi helyzet alkotmányosított egyenirányítása, politikai szélsőségek jóváhagyása és alkuképességének támogatása, kulturális uralom átvétele, tudástermelő szektor politikai megszállása stb.), hanem olyan passzív szereplehetőségeket is nyújtottak, amelyek egylogikájú értelmezése nem lehetséges pusztán a társadalmi mozgások, migrációk és stratifikációk szintjén, megértésük viszont célszerű lenne legalább a szimbolikus megjelenítődés területén.

Alább a politikai térról mint a fizikai tér egy elkülönült szegmentumáról fogok szólni, amelyet az uralomképes elit sajátít ki és növel egyre nagyobbra. A politikai tér - felfogásom szerint - a társadalmi térnek csupán egy része, de mert a politika és a társadalom nem valami szikével élesen elválasztottak, saját jelentésterén túl a politikai időnként társadalmivá válik, a társadalmiból olykor politikaivá alakul át számos térhasználati törekvés. Ilyen példát lelhetünk a hazai és határokon túli kisebbségi életszférában, ahol esetileg a kisebbség virtuális „nemzetté” áll össze identitás szempontjából, kialakítva valamely etnoterritorializációhoz kötheto, ,alliance”-alapú közösséget. ${ }^{5}$ Másutt épp e fixált státuszú térbeliség hiánya dominál (pl. a diaszpóra típusú kisebbségi világokban), s csökkenő trendet mutat a demográfiai vagy szociokulturális kapcsolatrend is.

A politikai rendszerváltás közeli negyedszázados időszakában a rendszerváltó politikai állam is a térbeli mozgás hordozója volt: „átmenet”, szokták-szoktuk mondani, átmenet valahonnan valahová, múltból a jövőbe, jelzős szocializmusból 
a jelzős kapitalizmusba, „vasfüggöny” mögül a schengeni előtérbe, a Balkánról a Nyugatba... Az átmenet rítusai a leválás és elkülönülés, a fennmaradás és működés, valamint a megtestesülés és integrálódás hármas lépcsőfokát kísérik, a régi jelképrendszerhez képest szokatlan, újszerủ interpretációval. Újszerűvel, mégpedig azért, mert nemcsak az Európa-szerte olykor fellazuló, máskor bomladozó nemzetállami viszonyrendszer részeivé váltunk - önkörünkben azért mégiscsak erőteljesen formálva a nemzeti tér kollektivisztikus építményének szegmentált változatát -, hanem mert a nagyhatalmaktól való függés történelmi korszakait hirtelen egy szuverenitásmegszerzési, vagyis szuverén térkitöltési lehetőség (olykor csak vágykép) váltotta föl, amely azonban „időzítését” tekintve nem jött jókor. A történelmi erőpróba, melyben a korábbi állapotát szétvető, dezintegrálódó Európa és a másik, az Egyesült Államok túlhatalmi súlyát korlátozni óhajtó integrálódó Európa immár nem a primer nemzeti szuverenitást, hanem a kollektivisztikus integrációt pártolja, épp ezekben a terekben és akut kurszakokban válik ellentétes törekvések platformjává. A leválás és elkülönülés parallel törekvése tehát az integrációban kiteljesedés törekvését hívta létre ott, ahol a nemzetfogalmak éltetői a földrajzi térfogalmakba (határokba, etnikai törésvonalakba, korábbi uralmi térbe, történeti kivetülésekbe) kapaszkodni próbálnak, s bár ez csupán a politikai tér külső feltételegyütteseként minősíthető, szükségképpen kiegészítette ezt egy belső történésrend is, amely a törvényt szabó, az életfolyamatok kontinuitását erőszak nélkül is fenntartó, a belső biztonságot a külső és belső lojalitásra építő állampolitikai törekvésekben fejeződhet ki. (Aktuálpolitikai analógiák nélkül is utalhatok itt a következőkre: a schengeni határ kérdése, a migrációs politikák változásának témaköre, a nagyregionális vagy határ menti kooperációk témaköre, a „Trianonra” és „NagyMagyarországra" való hivatkozások kampányai, az etnopolitikai dilemmák hosszú sora, a változó vagy megváltozott szomszédságfogalmak, a „nemzetbiztonsági kockázatok" szaporodó megjelenése stb. - egyáltalán, az európai egység és sokféleség nemzetközi politikai dilemmáitól függő politikai közhangulatok, az egységfogalmak, az integráció képzetei és normái, a be- és kiilleszkedés vehemens akaródzásai britek, görögök, törökök, magyarok, ukránok, moldovánok vagy gagauzok példái révén.)

Az általános térből a politikai és nemzetstratégiai tranzíció során kiválasztódtak a kitüntetett terek, s a térkitöltő megoldások egy új pozíció, egy új rendszer köznapi szerkezetét töltik meg. E ritualizált cselekvéssorban azonban már a rendszerváltás első évétől nem a társadalmi térszerkezet kiépítése zajlik, hanem a politikai elitek, a hatalomra került párt(ok) szimbolikus fölényének, a „politikai mediátorok" munkájának elfogadtatása, akik az eszmék és a társadalom mozgásait, a rendezettség látszatát vagy célját, az ideologikus tartalmú történések ünnepi térbe helyezését (szűkebb értelemben kizárólag a maguk cselekvésének legitimálását) próbálják biztosítani. ${ }^{6}$

$\mathrm{Az}$,általános” vagy univerzális térfelfogásban végbement ciklikusságot vagy a szimbolikus térképzetek jelentéstulajdonítási és értelmezési mezőkben 
rögzült formáit számosan megjelenítették már (pl. Bugovics 2004; Ilyés 2004; Krasznai 2012; Nemes Nagy 1996; Rechnitzer 1993). Az átmenet (mint azt a példák Spanyolországtól Tajvanig, Mexikótól Burundiig és Litvániától Csecsenföldig mindenütt mutatják) a rendszer-, és a politikai identitásváltozás, valamint a struktúramódosulás (többé-kevésbé) rendezett formája, amelynek legitimitása sok szempontból épp a térbeli (külső) környezet elfogadó gesztusától függ. Van persze számos (egyetemes) belső feltétele magának a kiterjedésváltozásnak, egyebek között a (megsokasodó és osztódó) plurális pártrendszer, mely módot ad marginális kispártok létrejöttére vagy helyi civil kezdeményezések pártosodási alakzatainak helykövetelésére, ugyanakkor a hatalommegosztás térségi rendszere is centralizált politikai térbe rendeli a függéseket - de ezeket most nem tárgyalom. Elegendő itt annyi következtetés, hogy a hatalom térbeli osztottságát illetően a rendszerváltozás ígéretében a társadalom és a politikai rendszer aktorai számára kiváltképpen fontos volt kezdetben, hogy a társadalomvezetés szétpontosítsa, demokratizálja a főhatalmat, vagyis centrális (térben is koncentrált) jellegét megszüntetve territoriálisan is megossza azt - részletekkel szolgál a rendszerváltás politikatudományi szakirodalma, kitűnő összefoglalóját lásd Ripp (2009), de elegendő Pálné Kovács Ilona munkáinak hosszú sorára utalni vagy Bodó és Biró elemzéseire a határon túli szférákból, Laki L. vagy Kapitányék monografikus áttekintésére nem különben. Ezzel a tendenciával ellentétben viszont a magyar rendszerváltás elnyúló éveiben, épp a jelenben újraközpontosodott, visszacentralizálódott a hatalmi szféra, újra kialakult a „hatalmi tér”, s mai verziója már egyértelműen a centralizált uralmi tér újraszervezése, az uralom térbeli ágazatainak átstrukturálása. Ugyanakkor mégiscsak megtörtént valamiképpen a politikai világ egyértelműen kommunikált újrafelosztása - mégpedig makro- és mikroszférára, amelyek bár részint korábban is megvoltak, de épp a deklarált demokratizálás miatt szembeszökő, mennyire más a pluralizálódás térbeni megvalósulása, mint ami a várva várt változás ígéretében szerepelt. Viszont a politika „újratársadalmasítása” úgy történt meg, hogy a társadalmi makroszférában elkülönült a politikai szféra keskeny és a társadalom széles pástja, s a mikroszféra ugyanígy kettévált a meglévő totalitás mikropolitikai hatástartományokra és a mikrotársadalmi térre. Természetesen a mikrotársadalom és a mikropolitika számára is megképződött a térben egyre távolodó makropolitikai tartomány, s a központi hatalom szférájától is eltávolodott a helyi politika és a helyi társadalom, viszont cserében a köztes-közvetítő terekben új funkcionalitások kezdenek létezni. Olyannyira, hogy a helyhatósági választások sok helyütt a nagypolitika pandantjaként és revansaként sikeredtek az első másfél évtizedben, s ma ennek épp ellenhatása látszik érvényesülni, mivel a helyi politika a nagypolitikai tér uradalmi cselédjévé, végrehajtó gépezetévé intézményesül. A centrumnak való alárendeltség következménye úgyszintén, hogy a listás országgyülési képviselőjelöltek igen nagy hányada lényegében semmiféle kötődéssel nem bír abban a helyi társadalmi térben, ahol versenyre kel a többi jelölttel. Vagyis a térbeli politikai távolság lényegében növekedett, 
még akkor is, ha a korábban sohasem látott méretekben érvényesülhetett az állampolgári politikai tagoltság kifejeződése a pártpreferenciákban és a politikai pluralizmus két választáson keresztüli megőrzésében vagy az önkormányzati miliőben életre kelő választási pártszerveződések és koalíciók alakjában.

Ez a térbeli tagoltság, osztottság, a politikai tér relatív növelése a társadalmi tér rovására a rendszerváltás egyik leglátványosabb virtuális történése, amit épp ennek ellenkezője kísért az ideológia szintjén, ahol a politika visszahúzódása a társadalmi térből kimondottan programos, ám korántsem valóságos volt. Nagyon is tanulságos, hogy miközben a nemzeti tér újrakialakítása korszakos program lett 1990-től, a települési tér még jobban elmosódott, a nem kellőképpen kondicionált társadalmi térben nagymértékủ mobilitás indult meg, ezen felül a virtuális társadalmi tér még átláthatatlanabb lett az MDF-kormányzat idején, s azóta sem változott definiálható módon. A politikai hatalom által uralt térben a politikai döntéshozók valóságos személye és társadalmi háttere köddé vált a társadalmi többség számára az MDF-korszaktól kezdődően, folytatódott valamelyest a koalíciós korszakokban, s csupán az utóbbi négy-nyolc évben kezd helyenként „nevesítődni” a helyi térben nyílt függelmi viszonyrendet fenntartók perszonális uralmi territóriuma (első és második Orbán-korszak). Újra erősödött, és számos esetben intézményesen (vagy legalább jelképesen) megjelent az alattvalói élmény, hogy továbbra is létezik a központi (irányító, uralkodói) akarat, amely a társadalmat és az önkormányzatokat vagy öntevékeny egyesüléseket a „törvényalkotó”, a ,jogalkotó” többletjogaival tartja kézben, az egyszeri szavazópolgár számára éppoly távoli erőként, mint amilyen (talán) mindig is volt (lásd erre példaként a „központi erőtér” vagy a „nemzeti együttmüködés rendszere" fogalmak közpolitikai sikerét). Ez a rendszerváltással egybeeső új „tereposztás”, amely a politikailag is tagolt teret uralmi térre és alattvalói térre felezi, nincs tekintettel arra, hogy maga a társadalmi egész elfogadja-e a modernizált gyámkodást, amelyet legföllebb a négyévenkénti voksolással színezhet át (de lényegén változtatni nem képes), vagy pedig visszautasítja azt a politikai stratégiát, amelyben a választópolgárok tömege nem más, mint hódítási terep a pártok számára, akik a közjó és a közakarat evidens megtestesítői. Az új hódítók (mintha Norberto Bobbio jóslatát teljesítenék be, amelyet A demokrácia jövője című kötetében vázolt fel) a politikai demokráciát úgy értelmezik, mint ha azonos volna a társadalmi demokráciával, s eközben jelentős tömegek épp a képviseleti demokratizálódásban nem képesek átélni a maguk érintettségét. Értékelésem szerint a magukat "demokratikus többség által megválasztottnak” tekintő kormányok olyan tekintély- és térkisajátitást vittek véghez szerte Kelet-Európában (ázsiai vagy afrikai példákról már ne is szóljak) - amilyet csak akartak. Tükrözte ezt a „privát szuverenitást” kiépítő szabadságot és a következményektől való félelmet a politikai változásokat vagy választásokat megelőző pártpolitikai kiegyezéskészség, amely arról szólt, hogy „ha minket támogat a nép, akkor önmagát támogatja", de azért a valóságban ne akarjon beleszólni senki a hatalom saját szuverén terébe...; s épp így tükrözte a „polgári rend” és a társadalmi 
„örök béke” fenntartásának igényére hivatkozó politikai kampányosság is, valamint az egyes képviselők menekülése a pártokból, a parlamenti pártok nyilvános vádaskodásai, a politikai tőkét a gazdasági tőkébe átmentő ügyintézői ügyeskedés, a területi adminisztrációt és igazgatást is átrajzoló belső megszállási projektek többsége stb.

Vagyis a rendszerváltó korszak politikai pártjainak stratégiájában igen nagy szerepet kapott a túlélésre, a létezés minimumára apelláló ígéret éppúgy, mint a különféle térszerző ellentámadások megsokasodása a politikai horizont két pólusán. A politikai tér jobb- és baloldali pólusokra osztottsága egyfelől a pluralizmus nyugati mintáinak, a parlamentáris alkotmányosság tradícióinak, illetőleg a pártok föltételezett partnerviszonyának szinte „bizonyítékává” vált, vagyis a „minimalizált” (tehát csoport-, párt-, vagy egyéni szintűvé lett) szuverenitás olyasfajta jelképpé növekedett, amelyet azok, akik magát a legitim változásfolyamatot elfogadták, józan ésszel vagy állampolgári érintettség okán nemigen kérdőjelezhettek meg. Mindezt végül a perszonális tér, a társadalmi közérzet és értékrend számos kondíciójának megromlása követte: a kényszerü kollektivisztikus álintegrációt megtagadni a nemzeti üdvözülés jelképe lett, de a hatalmi pozícióból „visszaadományozott” vagy állampolgári szintről „,visszahódított" személyesség egy újabb nagy kollektivitás, a nemzetgenerálás, az új demokratikus politikai függésrend kialakítása közepette veszett el ismét... - nem kevésszer (s épp legutóbb) akkor, midőn a legharsányabb volt a „nem leszünk gyarmat" avíttas megfogalmazása.

A térfogalom egyik klasszikus típusának, a jogilag elkülönült hatalmi szférának újramegjelenése nyomon követhető nálunk a pluralizálódó pártrendszer kezdőnapjaitól. Jelképesen is kifejeződik ez például a parlamenti padsorok elosztásának és a jobb/bal osztottságnak szemantikai problémákat okozó jelenségében (ki a baloldal, melyik a közép, ki áll a jobboldalon? stb.). A politikai pártok centrumba tolakodása persze a tradicionális parlamentarizmus hiányáról árulkodik, s aligha takarhatja el e pilléresedés nyilvános félreértésekre okot adó párttopológiai anomáliáit. Ha a bal vagy jobb térfélen foglal helyet valaki, s magamagát mégis középre képzeli, ezzel másokat minősít „rossz helyen” állónak vagy politikailag diszkrimináló helyzetbe hozhatónak. ${ }^{7}$ A „szimbolikus közép” horizontális megnyújtása okozza egyebek között, hogy a korábbi, egypártrendszeri politikai tagolatlansághoz képest valósággal törésvonalak alakultak ki, amelyeknek határait a kormányzat és a pártok szimbolikusan tologatni kezdték. Ez a jelképes huzi-voni a törzsi társadalmak háborúira emlékeztet, amelyekben a természetes (vagy szimbolikus) határok áthelyezése, illetve a dominanciák megszerzése-megerősítése a cél, és ritkán megy túl mindez a képletes ütközeteken, a határharcok szimbolikus újraértelmezésén vagy jóváhagyásán. Az „össztársadalmi”, vagyis totális dominanciabirtoklás azután már nyíltan ki is fejeződött abban, ahogy a kormányra jutott MDF népi-nemzeti-hazafias jelképtára elöntötte a nyilvánosságot, majd a következő választások politikai szimbólumainak szemrevételezésekor átszíneződött a politikai paletta, a szegfük burjánzottak el a választási térképeken és ural- 
ták a színes parlamenti padsorábrázolásokat, majd a színpompásan pipacsos mezőségben a magyar narancsolatot is elborította már a nemzeti trikolor vehemenciája. Mindezek pompás megnyilvánulásai a szimbolikus térbeélés, térfoglalás harsányságának, de annak is, milyen alku-, döntés- és érdektérben indulhatnak egyáltalán a politikai teret formáló alternatív törekvések.

A szimbolikus térfoglalásnak természetesen színpadi kellékei is vannak, közösségekhez tartozást, aktuális referenciacsoportot fejeznek ki (Buda 1993), s a szimbólumok mögötti jelentésstruktúra összetettsége mindig függ a kommunikációs szintektől, a jelentéstér szereplőitől, a dekódoló érzékenységtől, s különféle „premeditált és szintetizált jelentésektől”, amelyek a képekben sürüsödnek, a szimbólumok jelentéstöltetét adják, azok társaslélektani vetületét biztosítják. Így a szimbólum „szuperjelentés” lesz, s mint ilyen a kommunikáció nagyon hatékony, rövid idő alatt nagy jelentéstöltetet átadó eszköze, amely „nélkül új politikai konszenzusok nem hozhatók létre és nem tarthatók fenn" (Buda 1993). Ilyen szuperjelentés például a politikai főhatalom szuverenitása, érinthetetlen tere, amelyben a teljhatalom gyakorlása látszólag az „össznépi" konszenzuson nyugszik, s ezért rendkívül fontos a térbeliség képzetére gyakorolt hatása (vö. „a kétharmad mindent visz”, „nemzeti együttműködés rendszere" stb.). Ugyanis a klasszikus monolit teljhatalom esetén szóba sem jöhetett, hogy a szuverén szerep alulról megkérdőjelezhető lenne, hogy a minden közrendủ fölötti méltóság elvitatható vagy hogy a politikai uralom legitimitásához konszenzusos, az osztott társadalmi teret és polarizált akaratot is kifejező támogatottságra volna szükség. Vagyis bár ismét a „köz” tere vált a politikai reflexió tárgyává, a horizontálisan is osztott politikai térben az államügyek elvitathatatlan tulajdonlása a "magasabb szférák” lehetősége, birtoka, domíniuma lett. Ilyen értelemben a hatalom szuverenitása, épsége és sérthetetlensége attól az időtől kezdve privilegizált jog lett, hogy a „többségre” támaszkodó (avagy hivatkozó) politikai párt(ok) belekapaszkodhattak. A térbeli elkülönültség viszont - amint a mindennapi élet mediátorává válik és diskurzusgeneráló szerepe már semmiképp sem tagadható -, hatásával modellál, sőt manipulál is. Mindez szükségképpen van így a politikai közéletben, amely a diskurzus megjelenítője, akkor is, ha a jobb és bal osztottság nyilvánvalóan jelképesen sem fejezi ki a társadalom politikai tagoltságát, sem identikus valóságát.

Még az is lehetséges, hogy ebben nem a rendszerátalakító kormányzat(ok) a hibás(ak), s ezért nem a rendszer maga a felelős, hanem csupán a reprezentáció. Voltaképp és közelebbről az a politikai reprezentáció, amely reprezentáltakra és reprezentálókra osztja a társadalmat, amely szimbolikusan (vagy valóságosan is) kisajátított redisztribúciós eszköznek tekinti a társadalmi képviseletet, s amely a politikai horizont újrafelosztási lehetőségét hatalmi aktusként kezeli kitartóan, az állampolgárok fiktív egységével szemben pedig stabilizálja a politikusok, a központi és kiszolgáló technokraták elidegenült szféráját és a valódi társadalmi kapcsolatok, referenciák, számon kérő visszahatások nélkül is vígan müködő csoportját (lásd ehhez Appadurai 1996; Beck, Grande 2007; Mills 1972). 
A rendszerváltás folyamatában ez az új térfelosztás azért is feltűnő, mert a gazdasági és politikai válságjelenségek elleni legfőbb eszköz a jelképes egységesítés lett ismét, amely kifejezetten szimbolikus operáció, s arra szolgál, hogy legitimált megjelenítője legyen a közös „jó útnak”, a frissen kreált célnak és eredménynek (vö. „Magyarország jobban teljesít!”), amelyet egy politikai jelképiség révén a rendszer új szakértői, médiái, tudósai és tanácsadói népszerüsítenek, szervezett „actio popularis” alakzatban demonstratívan „meg is védenek” (lásd Békemenet, Kossuth téri permanens tüntetések időszakai). Elegendő itt a rendszerváltó kormányzat legitimitását megkérdőjelező egykori taxisblokád vagy az utolsó egyetemistasztrájkok, internetadó ellenes megmozdulás eseménytörténetére utalni, az agrártiltakozások fázisaira mint a „térbeliség válaszára” vagy a „kordonbontásra” mint határáthelyezési gesztusra a későbbi időszakban, majd az egész pályás letámadás elleni összevont demostrációkra a gazdasági válságot követő legutóbbi négy évben - s máris látszik mindezekből, hogy a közpolitikai köztérben zajló törzsi konfliktusok bár sokszínűek, de intenzitásuk és térformáló vagy térbirtoklási hatásuk nem terjed már ki a piramidális uralmi tér felsőbb régióinak légköréig).

\section{Eszmereprezentációk új (politikai) tere}

A politikai hatalom s az ő hivatalosan jóváhagyott, intézményesített szimbolizációja (pl. politikai térfelosztási kísérlete) kapott elsőbbséget ebben a politikai „közjóért” folyó küzdelemben, ráadásul oly módon, hogy a hatalom önszimbolizációja egyebek közt a nem verbális jelzéseknek, a szavak mögötti beszédnek, vagyis egyfajta kulturális univerzáliának alkalmazási lehetőségévé vált. A nemverbalitás politikai kultúrától függetlenül az ember társadalmi létéhez, interakcióihoz tartozó jelenség, amely a szociális szimbólumok és a társadalmi rendszer közötti korrelációkon (nem utolsósorban ennek térbeliségén) alapul. ${ }^{8}$

Az európai tér, a globalizációval szemben kritikai másként gondolást megtestesítő attitüd tizenéve legfőbb territóriumában persze a verbalitás eszköze, a politikai és térségi szintű egyeztetések, jogszabályok, kooperációk alapvető szervezőereje és intézményesülése. De magában a nem verbális kommunikációban is jelen van egy logikusan áttekinthető eszme. A magyarországi rendszerváltó állam esetében a társadalmi „szétesettség” helyetti „,nagy egység” mint krízismegoldás - valamiféle virtuális közösség formájában - reményt keltő eszmének, a kipukkadt, petyhüdtté vált politikai tér újrafeltöltődésének tűnhetett az 1990-es években. Viszont ez a szimbolikus politikai reprezentáció egyedül azon a primer hiten alapult, hogy a nagy egészen belüli kis egységek megjelenítésével a rendszer biztosítani képes a reprezentálandók reprezentációját. Ezzel szemben azt tapasztaltuk, hogy legjobb esetben is csupán magát a - Habermastól vett kifejezéssel - reprezentáció eszméjét reprezentálta. 
A politikai reprezentáció térbeli határait persze egyetlen alkotmány, szokásjog, makrotársadalmi érvényességű törvénycikk sem határozza meg vagy írhatja elő a normativitáson túli igénnyel és prediktív érvényességgel. További politikai térkérdés, hogy a hatalmi harcok logikájából eredő, a társadalmi képviselet gyakorlatát nem érvényesítő, csupán arra hivatkozó politikai masinéria igényt formálhat-e uralmi és térségi legitimitásra egyaránt, illetve hogy a társadalom makroegységét kialakító szándék, a virtuális nemzet képviseletének puszta deklarációja lehet-e hatékony a reprezentáció minimális szintjén, a helyi értékszférában is. Az a politikai reprezentáció, amelyben a küldetés, a „népakarat" jut kifejezésre (parlamentben, népképviseletben, képviselők képviseletében), egyfelől ugyan sajátos értékhordozó eszköz - de mert „minden érték” hordozója akar lenni, épp az „egységet” teszi lehetetlenné, épp a végtelen számú reprezentáltat hagyja figyelmen kívül, vagyis épp a maga katalizátorszerepét építi le. Ugyanazon központi kormányzati specifikus tér, amely a demokráciát, a liberalizmust vagy az összefogásra és egységre késztetést hirdeti meg, valamiféle jelképes politika helyszíne lesz, a változások levezénylésének metafizikai vagy mágikus tere. A politikai hatalom ugyanakkor épp a politikai tér ilyetén megkettőzése és a mágia előidézőjének feladattudata miatt nem képes tolerálni, hogy a társadalom mentális térképén nemcsak a jobb és a bal dimenziói léteznek, hanem annál jóval szélesebb társas kapcsolati térben és interakciók sűrü hálózatában van jelen az integritásigény, s emiatt a társadalmi többség a maga aspirációit nem érzi a politika nyelvére lefordítottnak, vagyis reprezentáltnak. Saját tere idegen tér által körülvett, saját fennhatósági jogosultsága a kívülről meghatározottság dimenziói közé szorult lett.

A térátélés változása a közelmúlt negyedszázad történetében két további lényeges momentumra hívja föl a figyelmet. Elsőként a geopolitikai makrofeltételre, a Szovjetunió korszakos térvesztésére, amely a gorbacsovi fordulattól kezdve a csatlósállamok szuverenitásnövekedésével, vagyis szimbolikus politikai terük visszanyerésével járt együtt (egészen a putyini időszak külpolitikai kríziseiig). Pedig mi tagadás, sok szempontból ez a regionális függésfeladás tette lehetővé számos országban magát a rendszerváltást is. A szovjet uralmi tér határbomlása (egyúttal mint időkomponens is) a múlt és a jövő szimbolikus határvonalának megjelenítődését eredményezte mellékesen, a kelet-európai régióban a szövetségesi elkötelezettségből való felszabadulás ígéretét is hozta. A határnyitás, a berlini fal leomlása, erőteljes tájolásváltás (a keleti centrumú politikai tér képe helyett az európai és nyugati orientáció értéknövekedése) történt meg, amely térátrendeződéssel egészült ki (migráló tömegekkel, a Varsói Szerződés felbontásával, NATO-val, uniós tagsággal, európaitagország-presztízzsel, gazdasági felzárkózással, képviseleti és támogatási aspirációkkal stb). Vagyis a korszak mint rendszerstabilizációs időszak, valamint a régió mint potenciális piaci térség és integrációtartomány kerül a társadalmi s eminensen a politikai szimbolizáció eszköztárába. A szuverenitás nemzetállami szintjének részbeni (lehetőségekbeni) visszanyerése, egyúttal egy nem kényszerített, hanem vállalt hová- 
tartozás kinyilvánítása (lásd pl. uniós népszavazás), virtuális és akusztikus megjelenése is lett, de fennen igényelte a deklarációk mellett a hathatós beilleszkedés megszervezését is (kelet-nyugati határok hangsúlyainak áthelyeződése, Schengen, piacorientációs váltás, pénzügyi uniós függés vagy késztetések, európaivá tágasodó társadalmi identitás, a „Nyugat” mint érték szimbolikus tőketöbbletének elsajátítása stb.). A térátrendeződés mint orientációváltás lehet (talán kevésbé látványosan) a mentális tőke része, de annál mélyebb hatású a piaci, migrációs, partnerségi, támogatási kapcsolatok, normatív dimenziók terén.

A térátélés változásához másodjára meg kell említeni az állami szuverenitás térstabilizáló attitűdjét, amely kezdve a „tizenöt millió magyar lélek” miniszterelnöki képviseletétől a visszakapott magyar nemzetállamiság külpolitikai túlhangsúlyozásáig, az ország területi integritásának később államnacionalizmusba fordult szélsőségességéig számos változatban megjelent. A szűkösnek bizonyuló nemzeti tér éppen az Antall-kormány fénykorában adott lehetőséget arra, hogy a „kibontakozás” belső akadályaként megnevezhető etnikai szférákat (zsidókat, cigányokat, román menekülteket stb.) a politikai pártosodás perifériáin minősítsék jelképes „kerékkötőnek” vagy érezzék a „szegény nemzet” nyakán élősködőknek, melyet a növekedő rasszizmus miatt, a tiszta nemzeti érdekek „veszélyeztetése” miatt a földrajzi térmegosztásban, térkisajátításban és térbirtoklásban megjelenő premodern tónusa napjainkban még hangzatosabb és egyszólamúbb retorikával ellátott „pávatáncoknak” kitetten alakít át korunk uralompolitikai stratégiája, mintegy újrafogalmazva a kelethez tartozás és a nyugathoz csatlakozás évezredes dilemmáját ez európai térben.

A nemzeti térigénnyel kapcsolatos hangulati elemnek pusztán szimbolikus térbeli-történeti meghosszabbítása volt a Horthy-korszak visszaidézése jelképes rangokban, tisztségekben, a két világháború közti szervezetekkel, árvalányhajas kalpaggal, turulszoborral, s ugyanilyen jelképes volt Horthy Miklós újratemetése mint szimbolikus térfoglalási eljárás, ugyanilyen térkiterjesztés volt „Nagymagyarország" mint külső tér sejtelmes belsővé tétele (a Duna-gate üggyel, a vajdasági magyarok iránti aggodalommal a balkáni háború idején, Tőkés László Nobel-békedíjra való jelölésével, a kolozsvári egyetem- és szoborvitába való bekapcsolódással, valamint kesernyés „Kompország”-közérzetünk gyakori újramegfogalmazásával, a határon túli magyarság szavazóképességének elérésével, új státusdiskurzusok szükségességének kinyilvánításával), nem is említve a harsány politikai retorika térnyerését a 2010 utáni nemzetpolitikai csúcsnarratívákban, „a nemzet főterének" totális átalakításával és restauratív szoborszimbolikákkal kiegészülve. Tegyem hozzá: a rendszerváltás utáni konzervatív nemzetpolitika ilyetén megvalósításában nemcsak a politikai közbeszéd kiszólásai voltak meghatározóak, s nemcsak a térszimbolizációs eljárásokban, bekebelezésekben és kiszorításokban harsány korszak írta át a korábbi történeti és földrajzi képzeteket-tudásokat. Hanem egyfajta narratív konszenzus is érvényesült, valamiféle társadalmi jóváhagyás halk kifejeződése is hangsúlyt kapott, amely mint a társadalom szimbolikus válasza, a rendszerváltó hatalmat a maga szekularizált terében elszigetelő közvélemény ellenében 
ugyancsak a diskurzusszférában hatotta át - persze másképpen a hazai szimbolikus politizálásban, a pártküzdelmekben és ideológiai csatározásokban, mint a határokon kívüli világokban. ${ }^{9}$

A térbirtoklás és a térszerzés mai, kortárs politikaelméleti dimenzióinak részletezésével talán egy másik tanulmányban kell közelebbi példákat soroljak. Itt ezt rövidre zárva, s mintegy konklúzióként hangsúlyozom: a politikai terek átrendezésének, átnevezésének és szimbolikus birtokbavételének nemcsak a párttagoltság térbelisége, a nemzeti vagy centrális akarat (ön)igazgatási eszközzé varázslása, s nem csupán a központi pártpolitikai érdektér átrajzolása adja meg új koordinátáit, hanem a tulajdonosi, partnerségi, hálózati térszerkezet átkomponálása, a politikai centrum és az alárendelt térségek viszonyának hierarchizálása, vidékpolitikában és ágazati területfelosztási játszmákban még intenzívebben mutatkozó táralakítási stratégiák kimunkálása is. Bourdieu az ilyen helyzetről úgy fogalmaz, hogy minden autoritás jogi aktusként kodifikálja müködését - ám a szimbolikus szférában nemcsak az elismert a legitim, hanem a tekintélyen túli performáció is, vagyis az, hogy legitimként fogadtat el olyan határdefiníciót, amely kijelöl és megvon, feloszt és értékel, felidéz és viszonyt határoz meg, tehát objektív valóságnak tüntet föl szubjektív célkitűzéseket (Bourdieu 1985). A térpolitika realizálódása, az új térszemlélet alakítása egyfelől a határ menti terek térkonstrukciós folyamataiban, másfelől az uralmi tér privatizálásának gyakorlatában (területpolitika, földtörvény, új birtokpolitikai stratégiák), harmadsorban az önkormányzati vs. állami vagyonok átrendezésében, s folyományként a stratégiai ágazatok új tulajdonosi szerkezetbe átrendeződével együtt járó térbirtoklási hitbizomány-kibocsátással zajlik. A felülről meghatározott tőke- és térkiárusítás, a hitbizományi érdekeltségi mező megteremtése a legtotálisabb beavatkozás az ötvenes-hatvanas évek tervutasításos rendszere óta. A kormány korszakos ideológiája a rendszerváltás kezdetétől „azé a tér, aki belakja” szlogen alapján funkcionál, lett légyen szó kárpótlási földekről, vagyonprivatizációról, önkormányzati lakáspiacról, tudomány- és kultúrafelügyeletről, energetikai érdekszférákról stb. Mindenütt a térbirtoklás előjoga alapozta meg az önvédelemre bátortalan helyi közösségek vagyonfosztását, gazdasági és mentális terük elorzását is. Szintúgy megképződtek a térfoglalás helyzetei a bankszférában, a tulajdonviszonyok számos új körülménye közepette - ahogyan Habermas (1994, 341.) írja: „a gazdaság és a közigazgatás valóban túlnőtt az életvilág horizontján”, emiatt a társadalom „tényleg annyira bonyolulttá vált, hogy aligha tárja fel magát belülről úgy, mint egy strukturális összefüggés dinamikus egészét”. Holott - folytatja - ,a funkcionálisan differenciált társadalom decentrált; már nem az állam a politika csúcsa, ahol az össztársadalmi funkciók összecsomósodhatnának: úgy tűnik, minden perifériává vált".

A periferizálódás, a történeti léptékű és térbeli kihatású részkérdések altémájával azonban már csak egy másik alkalmi áttekintésben lesz módom foglalkozni. 


\section{Jegyzetek}

1 Szimbolikus megjelenítődésnek azt nevezem, amit Habermas az identitás új feltételrendszerének leírásakor úgy fogalmaz meg, mint az egyedi és társadalmi „én” határainak megőrzését, valamint az élettörténet folytonosságának biztosítását tér- és időbeli szegmentálódással szétválasztó magatartást, amely az egyes életterületek vagy „parcellák” segítségével megpróbál eleget tenni a konzisztencia szokásos követelményének. Vagyis „a személy önazonosítás révén kialakított és fenntartott szimbolikus egységének", illetôleg a csoport szimbolikus realitásának kifejeződését nevezem szimbolikus reprezentációnak, amely azt mutatja meg, elhelyezhető-e az egyén egy csoport világában vagy a csoport a társadalomban (Habermas 1994, 141-143).

2 Bourdieu (1985) a szimbolikus politikai tőke változatainak elemzésekor utal arra, hogy a társadalom számára szimbolikus érdekek - szembefordulva az anyagi érdekekkel - függetlenednek azoktól vagy szimbolikusan megszüntetik érdek mivoltukat...

3 Paul Ricoeur a szimbólumot olyan, többletjelentéssel bíró kifejezésként határozta meg, amelyben az elsődleges jelentéshez a ráépülő átvitt értelmű jelentés analogikus kapcsolattal kötődik, e kettős jelentést pedig a szemantikai struktúra hordozza. Úgy vélte: a szimbólumok általános elméleteként megfogalmazható, hogy a gondolkodásnak saját megkövült hagyományait kell föllazítania ahhoz, hogy tudjunk szimbólumokban gondolkodni, de ne érezzük többé kielégítőnek, ha valamiről csak szimbólumokban tudunk gondolkodni. Elgondolásából kicseng annak belátása, hogy a szimbólum csak annyi gondolkodnivalót ad, amennyit a reflexió elhódít tőle (Ricoeur 1969, 484.). Intencióit készséggel követem.

4 Az antropológiai térfogalmakról minapában egész nemzetközi konferenciát rendeztek, az érdeklődő Olvasót a megjelent konferenciakötethez kalauzolnám (Géczi, András, 2014).

5 Lásd például a jászkun redempció és a „kunok civilizációja” térbeliségét, mely a Jászkun kerület közigazgatási alárendeltsége „fölé” emelkedve szimbolizálta a kisebbségi másság térségét két évszázadon át: http://terebess.hu/keletkultinfo/jaszok.html.

6 Erről két különböző időszakban és más ritualizációt elemezve egybehangzóan értekeznek Bodó J., Biró A. Z. (1993), illetve Voigt V. és munkatársai (1972); azóta pedig a ritualizáció folyamatának elemzését egy sereg „tranzitológiai” tanulmány és könyv elemzi eltérő dimenziókban, elég itt utalni Lengyel László (2014); Magyar Bálint (2013); Laki László (2009); Ripp Zoltán (2009); Kovách Imre (2011) köteteire és tapasztalataira vagy térpolitikai interpretációira.

7 Mintegy érdekességképpen jegyzem meg: kimutatták, hogy a jobb-bal dualitás egyfajta társadalmi nevelési minta és ritualizált illemszabályok révén lett hierarchizáló szimbólum, amelyben az emberi test értékeit a két oldal jellemzői szerint fogják fel, sőt ennek alapján tesznek közöttük értékkülönbséget (Hertz 1909).

8 E nem okvetlenül verbális kommunikáció megannyi árnyalatáról szól áttekintő elemzésekben, az uniós föderalizálódás, a földrajzi mellett kulturálisan fontossá váló politikai államszervezet és a légiessé váló európai nemzethatárok témakörében fogant esszégyűjteményében Konrád György (2014).

9 Izgalmas párhuzamok találhatók Krasznai (2012), valamint eltérő narrációk Bakk, Bodó (2003) kötetében.

\section{Irodalom}

Appadurai, A. (1996): Modernity at large. Cultural dimensions of globalization. University of Minnesota Press, Minneapolis

Arrighi, G. (1991): Siécle du marxisme, siécle de l'Amérique: formation et transformation du mouvement ouvrier mondial. In: Amin. S. (ed.): Le Grand Tumulte? Les mouvements sociaux dans l'économie-monde. Ed. La Découverte, Paris, 56-103. 
Augé, M. (1992): Non-lieux. Introduction a une anthropologie de la surmodernité. Éditions du Seuil, Paris

Bakk M., Bodó B. (szerk.) (2003): Státusdiskurzus. Esszék és tanulmányok. Szórvány Alapítvány, Diaszpóra Könyvek, Marineasa Kiadó, Temesvár

Beck, U., Grande, E. (2007): A kozmopolita Európa. Társadalom és politika a második modernitás korszakában. Belvedere Meridionale, Szeged

Berger, P. L., Luckmann, T. (1998): A valóság társadalmi felépitése. Tudásszociológiai értekezés. Jószöveg Kiadó, Budapest

Bodó J., Biró A. Z. (1993): Szimbolikus térfoglalási eljárások. Antropológiai Mühely, 2. 57-85.

Bourdieu, P. (1978): A szimbolikus tőke. In: A társadalmi egyenlőtlenségek újratermelése. Gondolat Kiadó, Budapest, 379-400.

Bourdieu, P. (1985): Az identitás és a reprezentáció. Szociológiai Figyelol, 1., 7-22.

Bourdieu, P., Boltanski, L. (1975): Le fétichisme de la langue. Actes de la Recherhe en Sciences Sociales, 4., 2-33. http://doi.org/bh4fhn

Buda B. (1993): Hozzászólás a szimbólum-vitához. Replika, 11-12. 142-147.

Bugovics Z. (2004): Helyi társadalom és területi identitás. Comitatus, 9., 5-19.

Deleuze, G. (1973): A quoi reconnait-on le structuralisme? In: Chatelet, F. (ed.): Histoire de la philosophie. Le XXe siècle, Hachette, Paris, 304-305.

Evans-Pritchard, E. E. (1940): The nuer: A description of the modes of livelihood and political institutions of a Nilotic people. Oxford University Press, Oxford

Fortes, M., Evans-Pritchard, E. E. (eds.) (1940): African political systems. Oxford University Press, New York.

Foucault, M. (1990): Felügyelet és büntetés. Gondolat Kiadó, Budapest

Géczi J., András F. (szerk.) (2014): A test mint antropológiai tér. Pannon Egyetem Modern Filológiai és Társadalomtudományi Kar, Társadalomtudományi Műhely, Veszprém

Geertz, C. (1994): A „bennszülöttek szemszögéből”. In: Az értelmezés hatalma. Századvég, Budapest, 227-245.

A. Gergely A. (1994a): Hatalom a színen - a kampányról politikai antropológiai aspektusból. JUSS, 1., 20-28.

A. Gergely A. (1994b): Rendszerváltoztatás és makrostruktúra. In: Várnai Gy. (szerk.): Kormány a mérlegen. A magyar kormányzat 1990-1994. Korridor Kötetek, Budapest, 54-77.

A. Gergely A. (1995): Bács-Kiskun megye színeváltozása. In: Bőhm A., Szoboszlai Gy. (szerk.): Parlamenti választások 1994. Politikai szociológiai körkép. MTA Politikai Tudományok Intézete, Budapest, 278-289.

A. Gergely A. (2014a): Kisebbségben: Téridő emlékezetben, tárgyakban, vallásban, névtelenül. Új Magyar Szó Online, február 17. http://www.maszol.ro/index.php/kisebbsegben/25055-kisebbsegben-terido-emlekezetben-targyakban-vallasban-nevtelenul

A. Gergely A. (2014b): Kisebbségben: Tér, társadalmi változás, értelmezési metszetek. Új Magyar Szó Online, március 17. http://www.maszol.ro/index.php/kisebbsegben/26390-kisebbsegben-tertarsadalmi-valtozas-ertelmezesi-metszetek

Gombár Cs. (1986): A politika parttalan világa. Kozmosz Könyvek, Budapest

Gombár Cs. (1996): Mire ölünkbe hullott, anakronisztikussá lett. Magyarország szuverenitásáról. In: Gombár Cs., Hankiss E., Lengyel L., Várnai Gy. (szerk.): A szuverenitás káprázata. Korridor Politikai Kutatások Központja, Budapest, 13-45.

Gunder-Frank, A. (1991): Les mouvemets sociaux dans l'histoire récente. In: Amin, S. (ed.): Le Grand Tumulte? Les mouvements sociaux dans l'économie-monde. La Découverte, Paris, 153-202.

Gyáni G. (2010): Az elveszithető múlt. Nyitott Könyvmühely, Budapest

Habermas, J. (1971): A társadalmi nyilvánosság szerkezetváltozása. Gondolat, Budapest

Habermas, J. (1994): Válogatott tanulmányok. Atlantisz, Budapest

Harrison, S. (1995): Four types of symbolic conflict. Journal of Royal Anthropology Institute, (N.S.), 1., 255-272.

Hertz, R. (1909): La prééminence de la droite: étude sur la polarité réligieuse. Revue philosophique, 68., 553-580.

Hobsbawm, E. (2009): Hétköznapi hősök. Ellenállók, lázadók és a dzsessz. L’Harmattan, Budapest

Ilyés Z. (2004): A határfogalom változó tartalmai a geográfiától az empirikus kultúrakutatásig. In: Kovács N., Osvát A., Szarka L. (szerk.): Tér és terep. Tanulmányok az etnicitás és az identitás kérdés- 
köréból III. Akadémiai Kiadó, Budapest, 9-15.

Ilyés Z. (2005): Az identitás mint kistérségi erőforrás - Gyimes példája. Kisebbségkutatás, 4., 460-467.

Kapitány Á., Kapitány G. (2013): A „szellemi termelési mód”. Kossuth Kiadó, Budapest

Konrád Gy. (2014): Itt, Európában. Európa Könyvkiadó, Budapest

Kovách I. (szerk.) (2011): Elitek a válság korában. Magyarországi elitek, kisebbségi magyar elitek. Argumentum, Budapest

Krasznai Z. (2012): Földrajztudomány, oktatás és propaganda. A nemzeti terület reprezentációja a két világháború közötti Magyarországon. Publikon Kiadó, Pécs

Laki L. (2009): A rendszerváltás, avagy a „nagy átalakulás”. Napvilág Kiadó, Budapest

Lengyel L. (2014): A szabadság melankóliája. Kossuth, Budapest.

Lévi-Strauss, C. (1958): Anthropologie structurale. Plon, Paris

Lowie, R. H. (1962): The origin of the state. Russell \& Russell, New York

Magyar B. (szerk.) (2013): A magyar polip. A posztkommunista maffiaállam. Noran Libro Kft., Budapest

Maine, H. S. (1959): Ancient law. Oxford University Press, London

Malinowski, B. (1960): A scientific theory of culture and other essays. Oxford University Press, New York

Mauss, M. (1950): Essai sur le don. In: Sociologie et anthropologie. Payot, Paris

Mills, C. W. (1972): Hatalom, politika, technokraták. Gondolat, Budapest

Morgan, L. H. (1961): Az ösi társadalom. Gondolat, Budapest

N. Kovács T. (2007): Helyek, kultúrák, szövegek: a kulturális idegenség reprezentációjáról. Csokonai Kiadó, Debrecen

Nemes Nagy J. (1996): Társadalmi térkategóriák a regionális tudományban. Egy modern tudományág mủhelyéből. MTA PTI Etnoregionális Kutatóközpontja, Budapest (Etnoregionális munkafüzetek; 17.)

Offe, C. (1991): Capitalism by democratic design? Democratic theory facing the triple transition in East Central Europe. Social Research, 4., 501-527.

Paul-Lévy, F., Segaud, M. (1983): Anthropologie de l'espace. Centre Georges Pompidou, Paris

Polányi K. (1972): Dahomey és a rabszolgakereskedelem. KJK, Budapest

Radcliffe-Brown, A. R. (1952): Structure and function in the primitive society. Free Press, Glencoe

Radcliffe-Brown, A. R. (1971): A rokonsági rendszerek vizsgálata. Szociológiai Füzetek, 1. 45-89.

Ratzel, F. (1882-1891): Anthropo-Geographie oder Grundzüge der Anwendung der Erdkunde auf die Geschichte, I-II. Engelhorn, Stuttgart

Rechnitzer J. (1993): Szétszakadás vagy felzárkózás? A térszerkezetet alakító innovációk. MTA RKK, Pécs

Ricoeur, P. (1969): Herméneutique des symboles et réflexion philosophique. In: Le conflit des interprétations. Seuil, Paris, 283-285.

Ripp Z. (2009): Eltékozolt esélyek. A rendszerváltás értelme és értelmezései. Napvilág Kiadó, Budapest

Schmitt, C. (1992): Politikai teológia. Négy fejezet a szuverenitás tanáról. ELTE JTK, Budapest

Schumpeter, J. A. (1980): A gazdasági fejlödés elmélete. KJK, Budapest

Valuch T. (2013): Magyar hétköznapok. Fejezetek a mindennapi élet történetéból a második világháborútól az ezredfordulóig. Napvilág, Budapest

Voigt V., Szépe Gy., Szerdahelyi I. (szerk.) (1975): Az 1972. május elsejei budapesti felvonulás társadalmi szemiotikája. In: Jel és közösség. Akadémiai Kiadó, Budapest, 187-199.

Wallerstein, I. (1991): Histoires et dilemmes des mouvements antisystémiques. In: Amin, S. (ed.): Le Grand Tumulte? Les mouvements sociaux dans l'économie-monde. Ed. La Découverte, Paris, $10-55$.

Zombory M. (2011): Az emlékezés térképei. Magyarország és a nemzeti azonosság 1989 után. L’Harmattan, Budapest 